\title{
The Tibetan Muslim Incident of 1960
}

In January 1959, Mao Zedong remarked ominously that " in the Tibetan area over the next several years, the enemy side and our side will compete for the [support of the] masses and test the ability of the armed forces.... [I]t is inevitable that a great showdown will occur." ${ }^{1}$ After eight years of pursuing a policy of accommodation within Tibet, the Chinese were growing weary of what they perceived as Tibetan resistance to Chinese rule. ${ }^{2}$ Predictably, as the Chinese tightened their controls, the number of Tibetan "pro-independence" and "self-determination" demonstrations rose dramatically. ${ }^{3}$

S. L. Chhibber, who arrived in 1956 as Indian consul general, was one of only a few foreign officials who had long-standing familiarity with Lhasa. ${ }^{4}$ Since 1936 , the British Mission in Lhasa had resided in a traditional Lhasa-style compound on the outskirts of the city known as the Dekyi Lingka (Garden of Happiness). In the years that Chhibber had been in Lhasa, he witnessed firsthand the slow rise in tensions between the Tibetans and the Chinese. He was also accustomed to the short periods of agitation exhibited by one side or the other followed by a tense reconciliation.

In January 1959, something different was in the air. Chhibber grew concerned enough that he began to offer detailed reports to his superiors in Delhi on the unmistakable vigilance and readiness being displayed by the Chinese in what seemed to him to be preparations for a clash. All around the city, stone watchtowers were suddenly constructed at intersections and other strategic points as the Chinese became "feverishly busy in strengthening their defense." ${ }^{5}$ These fortifications were erected on the top of the buildings where Chinese worked or lived. A sense of urgency permeated their actions, and when progress was deemed 
too slow, Chinese officials "requisitioned the services of their [Chinese] civilians, like barbers, hotel keepers, tailors, etc. to help them in making these [defenses]." ${ }^{\circ}$ Rumors began to circulate of the Chinese stocking emergency rations and digging wells inside their courtyards. In tandem with these defensive preparations, the Chinese officials also began to exert pressure on the Kashag to expel the Khampas who had been flowing in from eastern Tibet and who were perceived to be undermining the city's stability. The general inaction of the Kashag on the matter made an already tense situation worse.

Speculation surrounding impending Chinese troop reinforcements and the increased swirl of rumors suggesting Chinese plans to seize the Dalai Lama exacerbated the already unsettled mood in Lhasa. On March 10, 1959, amidst swirling accusations and denials between the Tibetan and Chinese authorities, large demonstrations by Tibetans became commonplace. Both Chinese and Tibetans seemed to be at the end of their patience. Tibetan groups, including government officials, monks, and heads of monasteries, as well as an assembly of several thousand women, began to organize themselves. A deputized committee approached the Nepalese and Indian consuls in Lhasa seeking their support, advice, and protection. In each instance the foreign officials indicated, apologetically, that despite their obvious distress they could not interfere in the domestic affairs of China. ${ }^{7}$ In response, Tibetans began to dress conspicuously in only Tibetan attire. Tibetan volunteers took up positions around strategic points. Tibetan employees of Chinese schools (and the Tibetans who attended them) were pressured to not attend work or school. Finally, the Dalai Lama and his closest advisers, unable to discern Chinese intentions and fearful of public consternation over the possibility of his being abducted, fled Lhasa on March 17, 1959, crossing the Himalayas and arriving in India two weeks later. ${ }^{8}$

On March 19, as news of the Dalai Lama's departure became known, Tibetans and Chinese, already tense, angry, and suspicious of one another, began a fierce fight for control of the city. ${ }^{9}$ The fighting that occurred in the 1959 March Uprising has been portrayed primarily in Anglo-European literature as Tibetan resistance and Chinese suppression. And seen broadly, such a description is not inaccurate. Yet as the historian Tsering Shakya has described, the reality was much more complicated. That complexity was due in part to the considerable anger Tibetans directed against the "Tibetan ruling élite who, they believed, had betrayed their leader [the Dalai Lama]." ${ }^{10}$ This anger, in the twenty-four hours after news of the Dalai Lama's departure became public, was not particularly rational, nor was it predominantly directed against the Chinese. Rather in these first hours the pentup outrage tended to occur as unpremeditated attacks on pro-Chinese Tibetan elites at traditional Tibetan centers.

The first individual to be attacked was Sampho (Tib. Sampho Tsewang Rinzin), and it would appear his assault came about not as political targeting 
but an unfortunate decision to wear Chinese rather than Tibetan-style clothing. He was a member of the original Tibetan delegation who had agreed in 1951 to the increasingly unpopular 17-Point Agreement that led to Chinese control of Tibet. At the time of his 1959 attack, Sampho held concurrent posts as Tibetan Army commander-in-chief and as the PLA Tibet Military Command vice-commander. As he approached the Norbulingka Summer Palace in Lhasa, dressed in a PLA uniform and riding in a military jeep driven by a Chinese driver, a large crowd surrounding the Summer Palace assumed he had pro-Chinese sympathies and began throwing stones. As he exited the jeep, a rock hit Sampho on the head. Injured and fearful of further violence, he fled to the nearby Indian Mission Hospital for treatment. ${ }^{11}$

The next pro-Chinese Tibetan to be attacked was a prominent member of the Chamdo Liberation Committee, Khunchung Sonam Gyamtso. He had entered the Norbulingka wearing traditional Tibetan clothing but later left in trousers, a white shirt, and with a white surgical mask covering his face-attire commonly worn by the Chinese. ${ }^{12}$ In Tsering Shakya's telling, "this simple act seems to have enraged the public, who attacked him and beat him to death." ${ }^{13}$ According to another account, he was "shot dead and his body taken round the streets of Lhasa in the most humiliating manner." ${ }^{14}$ The day ended, however, without overt military actions from either side.

The following day, March 20, began very differently. Tibetan rebels took up defensive positions at various points across the city, with the violence now deliberately targeting Chinese military forces and government buildings. At 10 A.M., in response to this provocation, the Chinese PLA was given the order "to take punitive action against the traitorous clique who had committed monstrous crimes." ${ }^{15}$ Clashes erupted across the city. Particularly bloody clashes occurred west of Lhasa around the Norbulingka Summer Palace and the Potala Palace, as Tibetan centers of resistance struggled to defend these important Lhasa landmarks and repel the organized Chinese military assault. Given the overwhelming firepower of the well-trained Chinese troops, the opposition had little chance of success. During the fighting, the Indian consulate, situated between Norbulingka and the center of Lhasa, was caught in the crossfire, with bullets striking the building, killing a Tibetan staff member. ${ }^{16}$ As the fighting spread into areas in and around the Barkor, the second story of the Nepalese consulate was also hit and damaged. ${ }^{17}$ The Chinese government gave no figures of Chinese or Tibetans killed, but it estimated that "more than 4,00o rebel troops were taken prisoner." 18

Almost as quickly as the fighting had begun, it drew to a close. Within twentyfour hours the Chinese flag flew over the Potala, dead Chinese soldiers and Tibetans littered the streets, and virtually all the Tibetan resistance had melted away. As a result, many Lhasans decided to follow the Dalai Lama over the Himalayas to India.

Rarely remarked is the fact that during the clashes on March 20, in addition to the "anti-collaborationist" violence at the Norbulingka and Potala, Tibetan 
groups attacked the Wapaling Khache community at the southeastern edge of Lhasa. This was unlike the attacks on individual Tibetans, for the violence directed at the Wapaling Khaches resulted in the destruction of their personal property, their homes, and their place of worship. By the end of the day, the centuries-old Grand Mosque and several dozen Wapaling Khache residences were burned to the ground. Wapaling Khache homes and shops along the market street were looted and ransacked. Despite the widespread attacks, not a single Chinese soldier was dispatched to protect the Wapaling Khaches or their property. Fearing for their lives, many Wapaling Khaches sought out the Chinese soldiers and took shelter in the PLA encampment outside the city. ${ }^{19}$

It is tempting to characterize the attacks on the Wapaling Muslims as a case of a minority population being caught in the crossfire of a violent insurgency, but that does not seem to be the case. The Wapaling Khaches had over the previous decade, in the eyes of many Tibetans, clearly become identified as colluding with the Chinese and thus became early targets of Tibetan violence. ${ }^{20}$ Tibetans made no secret of their open displeasure with the Wapaling Khaches' pro-Chinese stance. Some Tibetans suggested that not only did they offer aid to the PLA and Chinese officials, but when approached by Tibetans to help in the uprising, they were said to have staunchly refused. Nor did the violence against their community alter this attitude. According to the historian Tubten Khétsun, "During the subsequent violent suppression, many Muslim youths took up arms and accompanied the Chinese soldiers as translators, oppressing and terrorizing the Tibetans." ${ }^{21}$

With the departure of the Dalai Lama, with broad-based Tibetan resistance spent, and with the Chinese government abandoning all pretense of policies of accommodation, the period of the Wapaling Khache remaining politically ambivalent while benefiting from the Chinese came to an end. Deciding if one was Chinese or Tibetan became, for the Khache, a decision with far-reaching consequences. From this point forward, there would be no middle ground, and from the perspective of the Chinese government, there was only one choice: to embrace their Chinese identity or be labeled as a traitor.

Immediately following the 1959 March Uprising, the Beijing central government feared that its suppression of the uprising would be used to fuel accusations of the state being antireligious. They quickly sought to portray themselves as protectors of religion and denounced the Tibetan rebel attacks on the Wapaling Khaches as evidence of religious intolerance. Early state media reports of the Uprising portrayed the Wapaling Khaches as valiant defenders of the Chinese state against the treasonous and desperate measures of Tibetan rebels. Between the end of March and early May 1959, the People's Daily conspicuously featured the Wapaling Khache in a half-dozen front-page articles detailing the Uprising. The earliest article, on March 31, characterized them as local supporters of China's military response to the uprising. Wang Peisheng, a Lhasa-born Wapaling Khache and a prominent pro-Chinese Khache, was quoted as asserting, "The overwhelming majority of 
Lhasa's Hui are patriotic, and we, the entire Hui people, will steadfastly follow the Communist Party." ${ }^{22}$ Two days later, on April 2, a front-page article appeared with the headline, "The People of Tibet Enthusiastically Uphold Suppression of Rebels," in which two senior Wapaling imams decried "the rebels' monstrous crimes of looting and burning Lhasa." The article noted that the rebels" "crimes reached up to the heavens and brought calamity to both the country and the people." ${ }^{23}$

Two weeks later, in mid-April, a front-page article denounced the Tibetan rebels, profiling over two hundred Wapaling Khaches and highlighting the harm done to them. In the article one Wapaling Khache, Ma Mingliang, berated the Tibetan rebels, insisting, not inaccurately, that the Khaches had been targeted "only because they were opposed to the rebellion and refused to participate in the pro-uprising rallies." ${ }^{24}$ In late April, two more People's Daily articles appeared. By this point, the thrust of the articles shifted from the trauma endured by "normal Tibetans" at the hands of Tibetan rebels to the rebels' purported heartless behavior towards the Khache. The articles, far from defending the Khache, primarily were interested in undermining the commonly held view of Tibetans as peace-loving Buddhists.

By twisting the manner in which the rebel violence had affected the Tibetan Muslims who had lived in Tibet for generations, the state press sought to subvert the commonly held notion that Tibetans generally, and the rebels specifically, were innately harmonious and nonviolent. The first article was titled "Inhuman! Deplorable! Tibetan Rebels Heinously Murder by Ripping Out Hearts!" In an accompanying photo, Muslims are shown holding Friday prayers in the burned-out shell of the Grand Mosque. The headline of the second article, “Tibetan Rebel's 'Protect Religion Army," deliberately underscored the irony of the rebel's moniker by demonstrating their antireligious actions against Muslims. The article is juxtaposed to a photo of a Wapaling Khache standing forlornly in the remnants of his burned-out home. ${ }^{25}$ Employed in this manner, the Wapaling Khache remained powerful instruments of the Chinese central government's claim that the Tibetan rebels were a minority intent on reversing the positive achievements of the People's Republic since its arrival in Lhasa.

In the weeks and months after the uprising, many Tibetan leaders were arrested, imprisoned, and often publicly criticized for their crimes during mandatory public rallies. All citizens of Lhasa were expected to show their support of the Chinese by insulting, spitting on, and, in some cases, beating the former leaders. Often individuals selected to lead such demonstrations were those who had personal grudges against the ones who were imprisoned. In one case, Chinese authorities selected Ghulam Muhammad, a well-known Wapaling Khache, to publicly criticize a Tibetan accused of crimes against the state. ${ }^{26}$

By early May, the prominent reporting of the Wapaling in Chinese state media suddenly ended. This dramatic change reflected the broader shift in Chinese central government's strategy, which shifted the focus away from the Tibetan 
rebels' antirevolutionary actions towards one establishing India's central role in organizing the uprising. ${ }^{27}$ On May 6, the day after the last article in which Tibetan Muslims were prominently featured, this new anti-India offensive began with the People's Daily banner headline reading, "The Revolution in Tibet and the Philosophy of Nehru." ${ }^{28}$ The long, 18,000-character editorial filled the entire first two pages of the paper. While saying little about Nehru's philosophy, the article articulately, and with choice use of Nehru's own words, attacked the Indian leader's views on Tibet's autonomy. Taking particular issue with how some Indians characterized "Tibetan autonomy," the editorial scathingly rebutted commonly held Indian perceptions of Tibet as a protectorate or buffer state of China:

Some politicians in India regard China's "suzerainty" over Tibet like that inherited from the British tradition of the past: suggesting China's so-called "suzerainty" over Tibet is like India’s "suzerainty" over Bhutan and Sikkim. . . . It is true that Tibet is not a province but an autonomous region of the People's Republic of China. An autonomous region has more constitutional and legal rights than provinces. The province has more authority under the Constitution and the law. But Tibet is definitely not a protectorate-neither a protectorate of China nor a protectorate of India, nor a joint Chinese-Indian protectorate, nor is it a so-called buffer state between India and China. The People's Republic of China enjoys full sovereignty over Tibet, just like it does over Inner Mongolia, Xinjiang, Guangxi, Ningxia [autonomous regions]. These facts are not even in the slightest degree in question, and no foreign country or the United Nations are allowed to interfere in any name or form. ${ }^{29}$

Alternating between deeply polemical language and scathing sarcasm, the editorial advised Nehru to pay more attention to his own country's problems and leave those of Tibet to China.

One also finds a subtle degree of introspective self-criticism. It went as far as to suggest that the Chinese government had waited too long, coddling the misguided efforts of Tibet's errant traditional elite. Only now, by listening to the will of Tibet's lower classes, was the Chinese leadership going to alter Tibet for the better:

In Tibet, we displayed especially great patience in order to win the cooperation of Tibetan upper strata elements. For eight long years since the liberation of Tibet we maintained intact the former Tibet Local Government, its complete system, its army and even its currency and persuaded the people of Tibet not to carry out for the time being the reforms they urgently demand. ${ }^{30}$

While China's dissatisfaction with India emerged from many quarters, there is little doubt that by late May, the Khaches' claim of Indian citizenship had unexpectedly become a potential liability for the Chinese government.

Observant Chinese, now quite attuned to such rapid shifts in the political winds, would have realized that the Khache's absence from the state media was a clear sign their political stock had plummeted. However, it would have been difficult for any but those intimately familiar with Tibet to understand the continued role 
the Khache played in the Chinese government's growing unease over the situation. Part of the difficulty lies in the People's Daily's choice to refer to the Khache, generically and uniformly, as Hui (Muslim Chinese). As in the years leading up to the 1959 March Uprising, no mention or distinction was ever publicly made of the diversity within the Lhasa Muslim community ${ }^{31}$ Never, for example, did the media reports divulge that while Tibetans did raze the Wapaling Khache mosque, they neither desecrated the Barkor Small Mosque nor damaged a single Barkor Khache home. Not surprisingly, Chinese government coverage avoided mentioning the Wapaling Khaches' role as translators for Chinese soldiers and officials or that Tibetans accused them of "behav[ing] with unlimited arrogance." ${ }^{2}$

In the state newspapers, the Khaches' swift descent from fame to obscurity was a result of deliberate expediency, not unintended ignorance. In the hours after the uprising, and as quickly as the government acted to promote the victimization of the Wapaling Khache, they also moved to suppress what they considered to be the Barkor Khache threat to the city's tenuous calm. On March 21, the very day they secured control of Lhasa after the uprising, the Chinese detained and arrested Hamidulla (Rapse) Masle, senior leader (Tib. kha che dpon po) of the traditional Khache council. ${ }^{33}$ This action was followed by two other arrests, and the entire council was in prison by the end of the year. Within the week, Chinese officials informed the Barkor Khache that all "previous laws and documents [regarding their Indian citizenship] were to be deemed as cancelled, and no claim was to be accepted unless it was backed by fresh documentary proof." 34

On April 1, Chinese officials went to the Barkor Khache residences and businesses inquiring about their "race and nationality" while demanding at the same time that they declare themselves Chinese. Those who refused were taken for extended interrogation sessions that resulted in several Barkor Khaches being forcibly coerced into declaring themselves Chinese citizens. ${ }^{35}$ Throughout this period, the Barkor Khache were forbidden from gathering in groups of more than three people. ${ }^{36}$ Even as they disputed their citizenship, officials demanded they participate in various indoctrination and propaganda meetings, under the threat of being taken into custody. ${ }^{37}$

\section{TO BE TIBETAN IS NOT TO BE CHINESE}

The Indian consulate was one of only three foreign missions in Lhasa, along with the Nepalese consul general and the Bhutan Mission. It was in 1947, with India's independence, that the consulate was transferred from British to Indian control, and a succession of Indian consuls had occupied the post over the next decade. Since his posting to Lhasa in 1956, Chhibber had made it a point to become familiar with the Khache community, and their decision to approach him was not unexpected..$^{8}$ In the face of these aggressive tactics, as Ramadan 
came to an end in early April, the Barkor Khache leaders "approached the Indian Consulate for aid, whereby they hoped to bring about the migration of the whole [community to India]." ${ }^{39}$ Having traveled back and forth to India for decades if not centuries, the Barkor Khache were familiar with Indian culture, customs, and government. Many Khaches sent their children to school in India, and a small but substantial minority had moved to Kalimpong, Darjeeling, and elsewhere there.

Presciently, Chhibber had addressed the question of the Tibetan Muslims' nationality on April 27, 1958. Nearly a year before the Dalai Lama left Tibet, the Indian consul general in Lhasa and his Chinese counterpart, the director of the Foreign Affairs Bureau in Tibet, had discussed the issue. ${ }^{40}$ That autumn, Chhibber again informed his superiors in Delhi that the "Muslims in Lhasa, especially those who have origin in Kashmir, are worried about their future. Some of them have approached us for registration as Indian citizens." ${ }^{41}$ The 1959 March Uprising had both raised the stakes and dramatically altered the context of this issue.

Taking up the issue again in a note to the Chinese dated May 1959, Chhibber contended that his own investigation into the matter had led him to conclude that "the Kashmiri Muslims and other Indians living in Lhasa and Shigatse should be treated as Indian nationals." ${ }^{42}$ Two months later, when the Chinese finally offered a response, it was equally concise and unequivocal: "These assertions are opposed to the historical facts and I cannot agree with them." 43 Not deterred by China's position, the Barkor Khache approached the Foreign Affairs Bureau to ask how to legally declare themselves Indian citizens and were told they needed to present Indian passports. Then, according to Chhibber's account, about "four to five hundred Muslims of Kashmir origin, who had never approached us earlier" came to him asking to register as Indian citizens. ${ }^{44}$ After asking for and receiving his government's approval, he distributed forms to register them as Indian citizens. Just as the Barkor Khache prepared to submit the forms, the Chinese officials seized all their documents and declared them null and void. The Barkor Khache were then informed that any further efforts to prove their foreign citizenship would be considered illegal. ${ }^{45}$ The local Chinese authorities then posted guards outside the consulate to prevent further communication between the Khache and the consul general. Throughout July and August 1959, groups of Barkor Khache that approached the Indian consulate were repeatedly "turned away by force." ${ }^{4} 6$

Adding a new wrinkle to the Chinese state's insistence that Tibet had been an integral part of China since the Yuan dynasty, Chinese officials maintained that all the residents of Tibet were Chinese citizens regardless of origin. While the Barkor Khaches were the obvious target of this policy, several hundred Ladakhi Buddhists who had never required passports or papers to cross the border into India were now detained and told they needed to produce documentary evidence of their 
country of origin. In a testy response to Chhibber, the director of the Foreign Affairs Bureau in Tibet lectured the Indian government:

As everybody knows, among the inhabitants in Tibet of our country, there are a number of people of Islamic faith. Besides the Hui from such provinces as $\mathrm{Yu}[\mathrm{n}] \mathrm{nan}$ and Sichuan these are some whom we call Kachis [Khache]. Although their forefathers were from Kashmir, yet as early as the 17th century, during the time of the Dalai Lama, their forefathers had already chosen the Chinese nationality and had thus become a component part of the Tibetan people of China. ${ }^{47}$

These historical assertions did little to clarify why the Chinese government had not instituted such steps earlier or how such a view accommodated the realities of Tibetan autonomy under the Nationalists in the first half of the century. Nor does it explain how, according to the memoirs of the Chinese diplomat Yang Gongsu, the Khache had for many years been raising the question of their "Indian ancestry" (Ch. yindu ji). In his account, the Khache had first approached the Kashag in 1956, who in turn referred them to the Chinese Foreign Affairs Bureau. The Foreign Affairs Bureau rejected their request because it was "in violation of China's foreign policy," and also because the "Kashag had in the past consistently treated them as Tibetan." 48

These specific inconsistencies added to the more general impression that the Chinese government had suddenly, in 1959, adopted a blanket policy forcing all individuals, with or without proof of foreign citizenship, to accept Chinese citizenship. The Chinese officials in the post-Uprising period seemed to be primarily interested in establishing a policy that would uphold their contention that all residents of Tibet were Chinese. They preferred this to sorting through the complicated pastiche of citizenship claims they faced, fearing that such a process would result in Tibetans claiming non-Chinese citizenship and make an already awkward situation worse.

The problem with the Chinese government's efforts to impose a one-size-fits-all solution on Tibet was that even in obvious cases of foreign citizenship, China's own national interpretations of citizenship laws were being ignored. In one instance, eight Nepalese, whose government had a recognized diplomatic mission and a representative in Lhasa, were arrested and held without charge. When the Nepalese consul general demanded their release, the Chinese replied that "there was no special law for foreigners and that their cases would be taken up under the law of the land." 49 Even those Nepalese who were not arrested, such as Nepali traders, were given the choice of returning to Nepal or remaining in Tibet, recognizing that if they remained their movements would be restricted to Lhasa, severely hindering their livelihood as traders.

By August, the constantly fluctuating situation for Lhasa's Khache, Nepalese, and mixed-nationality populations reflected China's new autocratic stance toward Tibet. China's new posture and policy were unambiguous. Tibet was a part of China, and no concessions were to be sanctioned. The consequences were immediate and pervasive. Chhibber disconsolately summarized this in his monthly report at the 
end of summer 1959, "With the overwhelming number of Chinese troops and cadres the local opposition has completely been overcome. The younger generation in particular have been taking active part in the pro-Chinese programs and activities." ${ }^{\circ 0}$ Chinese authorities began to tighten control over every aspect of life in the city. All residents of Lhasa were rounded up and over the course of three days fingerprinted, cataloged, and issued identity cards..$^{51}$

During this period, disinformation was rampant. Chinese officials and residents began circulating a rumor that the Dalai Lama was being detained against his will in India, and this led to a group of nearly five hundred Tibetan women storming the Indian consulate, "refusing to leave the premises unless some proof of the Dalai Lama's free movement was shown to them." ${ }^{22}$ In June, the Chinese government circulated the news that Chinese currency would become the only legal tender; foreign and Tibetan currency would no longer be accepted..$^{53}$ Two months later, officials formally instituted the currency regulations but would convert Tibetan currency at only 20 percent of its face value. ${ }^{54}$ With little or no advance warning, the foreign and Tibetan traders, who had been commercially prosperous until March, were faced with financial ruin, as most of their assets were in Indian rupees or silver dollars. When the news of China's actions reached India, silver prices shot up as bullion traders panicked over the prospect of a curtailed supply of silver from Tibet. ${ }^{55}$

By August, China and India appeared to be at loggerheads over the Barkor Khache. In mid-August, India's ambassador delivered a diplomatic note to the Foreign Ministry in Beijing. In the note he accused local Lhasa officials of arresting a Barkor Khache on August 6 who had refused to attend a neighborhood meeting intended for local residents. In response to the Barkor Khache's arrest, "two to three hundred of his compatriots went in protest to the Foreign [Affairs] Bureau." Later, when fifty to sixty Barkor Khaches "endeavored to come to the Indian Consulate," they were "prevented by the Chinese guards at the point of weapons." ${ }^{6}$ While Chhibber assiduously maintained very careful relations with all Tibetans, the Chinese expressed unhappiness with the Indian consul general's behavior. Having already served for nearly three years, longer than any of his predecessors, the Indian government made the judicious decision to move Chhibber to a new post.

While not exactly unanticipated, Chhibber's departure was warmly welcomed by the Chinese. If the Chinese believed that his replacement would be less troublesome, they were to be disappointed. The appointment of P. N. Kaul, a career diplomat hastily transferred in from Romania, marked an astute shift in tactics by India in Tibet. With his arrival, the Barkor Khaches' status became a central concern of the Indian government.

\section{INDIA AND THE “KASHMIRI MUSLIMS”}

If the question of whether the Barkor Khache were Tibetan, and thus Chinese, dominated the discourse in Lhasa, in India the question initially centered on 
the dilemma of whether they should be considered Kashmiri and thus Indian citizens. Indian diplomats, politicians, and reporters tended to use a hodgepodge of terminology to refer to them. Consul General Chhibber, in his May 1959 communication to his Chinese counterpart in the Tibetan Foreign Bureau, refers to them as "Indian Muslims from Kashmir," or "Muslims of Jammu and Kashmir origin," or "Kashmiri Muslims." ${ }_{57}$ The Indian press, and even the New York Times, repeatedly referred to the Barkor Khaches simply as "Indian nationals" or as "Indian traders," emphasizing their rights as Indians. From the Chinese perspective, all Muslims in Tibet, whether they were Barkor Khache, Wapaling Khache, or Muslims from Beijing living in Tibet, were all Hui and without exception were considered Chinese citizens.

Initially, the Barkor Khache mustered historical evidence to put their case in the best light possible, even if the proofs they chose to use were selective, fragmentary, or deliberately taken out of context. At first, in seeking to prove that they were foreign, not simply of foreign ancestry, they often purposely conflated their position with that of the Ladakhi community by playing into the ongoing confusion over Khache/Kashmiri terminology. Given their clear-cut pre-1951 status as Tibetan, the Barkor Khache appeared to be unsure of the best path forward to prove their Indian ancestry. In the face of the persistent Chinese assertion that to be Tibetan is to be Chinese, they sought to play to the common (albeit false) notion that in the eyes of the Tibetan government they had been like the Ladakhi in order to prove their claims. The "evidence" they provided was a mixture of half-truths and white lies that played to the Chinese ignorance of Tibetan society, including that they were "tax exempt", that they were self-ruled by the Khache council, and, citing a Tibetan dictionary, that they were defined as "Kashmiri." 58 The Chinese never directly refuted the Barkor Khaches' argument but simply indicated that none of this definitively proved they were not Tibetan and thus were Chinese.

In the months immediately after the Uprising, Indian officials were equally at a loss as to how to prove that the Khache were Kashmiri and thus Indian. In the Indian parliament, Nehru's response to queries about Indian citizens arrested by Chinese forces at first suggested it was just a matter of clarification: "We have approached the Chinese authorities to permit Muslims from Kashmir as well as Ladakhi Lamas to contact our Consulate in Lhasa and to allow them to return to India if they so wish." When immediately pressed for more details, Nehru could only state:

Two types of Indians went there [Tibet]; the one were the [Buddhist] Lamas and they went for study there; the other were Ladakhi Muslims who sued to go for trade. According to our old practice nobody need get the papers and most of them did not. So, we had no record.... The Chinese authorities have raised the point that these people are no longer Indian citizens if ever they were because many of the Kashmiris-Ladakhi Muslims- have been there for a long time. That is a matter on which we are conferring with them. ${ }^{59}$ 
Yet, when immediately pressed again, Nehru elucidated with even greater clarity:

There is no question of mistaken identity. It is a question of a person establishing his nationality, not identity. Nationality is normally established by papers, passports etc. Now, they have no papers and passports except such oral or other evidence they might give. Immediately it becomes a little less definite although it might be established. It depends upon the authorities taking a strict view or a flexible view about it. They [Khache] have said quite definitely that they are Indian nationals from Kashmir. ${ }^{60}$

Clearly, Nehru, by September 1959, had already concluded that the Barkor Khache met the criteria to be considered Indian citizens.

Despite Nehru's newfound confidence, it was only months earlier that Indian and Chinese officials appeared far less sanguine about their positions vis-àvis the Khache. In May 1959, a group of Tibetan Muslims on hajj found themselves stranded in Bombay and without international travel documents. Having left Lhasa prior to the political tensions, the pilgrims, as customary for several decades, had been allowed to cross the Indian border with the simple notation that they were pilgrims traveling to Mecca via Bombay. ${ }^{61}$ For many years Bombay had functioned as the primary exit port for Muslims traveling to Jeddah by boat on their hajj to Mecca. The presence of Tibetan Muslims would not have attracted attention in the past, but as this group attempted to board the boat, Indian agents discovered their lack of international travel papers and they were stopped. A progressively stringent enforcement of hajj travelers' identity had begun under the British in the 1930s, making their plight a not uncommon occurrence. What made this story newsworthy was the fact that when the Tibetan Muslims approached the Chinese consulate in Bombay, the Chinese refused to issue them passports or to claim them as Chinese citizens.

Alerted to their plight when he saw a picture of them in a newspaper, Nehru personally raised the matter with his foreign secretary, Subimal Dutt, asking him to intervene on their behalf. Several days later, Morarji Desai, the Indian finance minister, was dispatched to meet with them at the hajj Pilgrims Welfare Committee office in Bombay and facilitated their departure. ${ }^{62}$ Nehru's growing interest in the Khache issue almost certainly stemmed from the immense domestic and international acclaim he had received because of his treatment of the Dalai Lama. In early July, he would write again to Dutt regarding China's increasingly belligerent behavior towards India's consulate officials and the continuing anti-India abuse in the Chinese media: "I have been wondering if we have done all we could in these matters. The impression created in my mind is that the Chinese authorities in Tibet are behaving very badly and are trying to squeeze out our people." ${ }^{3}$ As Nehru began to orchestrate a state response to resolve the Khache issue in Tibet, other Tibetan Muslims in India also began to mobilize their resources. 
A small Tibetan Muslim community had existed in Kalimpong since at least the 1930 s and had retained strong connections to the Barkor Khache in Lhasa. As the situation deteriorated in Lhasa, they were the first group that the Lhasa Khache attempted to contact for assistance. Their first letter, written in Urdu to escape Chinese detection and smuggled out by Tibetan traders, arrived in late April. This letter outlined the basis for their claim to be Indian citizens, almost as if to signal their strategy with a single voice to those Khache in India:

\begin{abstract}
It is vitally important for us to let you know that the Chinese Government, after the recent trouble in Lhasa, has threateningly asked us about our ancestry. In reply we have declared ourselves with cogent evidence as Kashmiris and subjects of INDIA. The Chinese Government is trying its best to subjugate us and make us Chinese Nationals. With great perseverance and sacrifice we reported the matter to the Chinese Government as well as to the Indian Counsel in DEKILINGA. The Indian Counsel at Dikilinga is also striving hard for us by representing to the Chinese Government that we are INDIAN NATIONALS, and you might have heard it on the Radio. ${ }^{64}$
\end{abstract}

The overall tone of the letter is one of extreme urgency. It repeatedly emphasized their dire circumstances in Lhasa and ardently demanded the assistance of those Khaches living in Kalimpong. The authors of the letter cast their appeal in multiple registers, including their obligation as Muslims: "It is a question of the entire generation whether it will cling to its faith or turn infidel. ... Muslims and specifically our own kith and kin must not sit idly by enjoying comfort and remaining indifferent." 65 The letter concludes by addressing the two Khaches in Kalimpong by name and calling their request a "test from Allah." A second letter from them was received several months later and said plaintively, clearly at their wits' end, "we were hopeful after our last letter that you would surely do something for us. But we sadly noted that nothing was done." ${ }^{66}$ In spite of their concern, many among the Khache in Kalimpong had taken up their cause, none more than Fazullah Chisti. Chisti, a prominent citizen of Kalimpong had in the past aided Khaches in securing needed Indian transit permits and passage on the annual hajj boats from Bombay. Immediately after receiving the first letter, Chisti had approached Indian officials with memoranda and face-to-face meetings. ${ }^{67}$

By late August 1959, several factors converged to facilitate the Kalimpong efforts to raise awareness of their fellow Khaches' plight in Lhasa. Chisti led a fourmember delegation from Kalimpong to New Delhi to "meet Mr. Nehru and other members of the Cabinet and ... apprise them of the difficulties being faced by Indian traders in Tibet." ${ }^{68}$ As noted above, his timing coincided fortuitously with the Indian government's renewed efforts to discover a process by which to resolve the issue. Indian public opinion also became more interested as a result of a flurry of front-page articles in early to mid-August that pushed for a resolution to the Khaches' situation. ${ }^{69}$ 


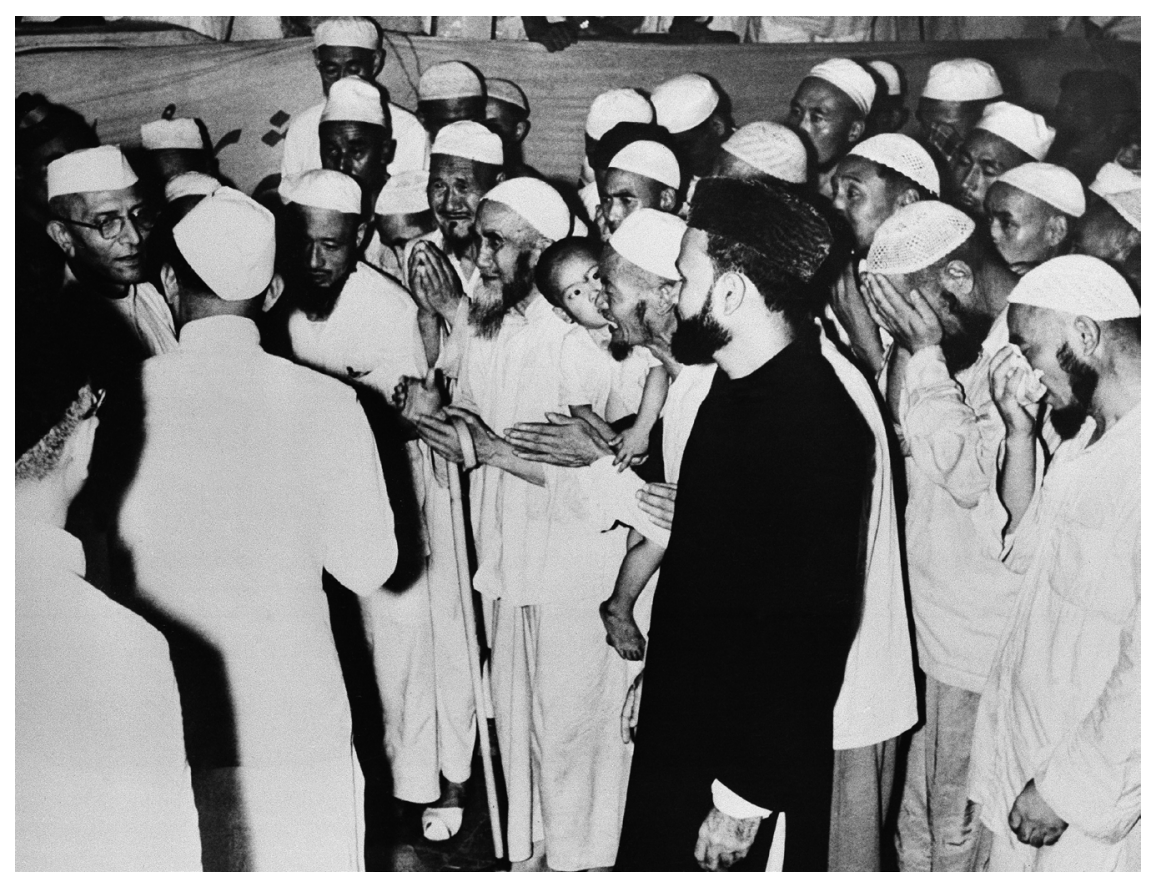

Tibetan Muslims at the Haj Pilgrims Welfare Committee office in Bombay, India, pleading with Morarji Desai, Indian finance minister, May 28, 1959. Copyright AP Photo.

From spring to late summer of 1959, the parameters of the dispute over the Barkor Khache remained for all parties involved-Indian, Chinese, and the Khache-largely a reiteration of previous assertions about (1) the historical status of the Khache under the Tibetan government prior to 1950, (2) the issuing agency of the Khaches' passport or visa to travel to Mecca on the hajj, and, often, (3) the assertion that the term "Khache" meant Kashmiri and thus, ipso facto, the Khache should be adjudged to be Indian citizens..$^{70}$ In late August, however, two seemingly unconnected events-a skirmish at the Sino-Indian border outpost of Longju and an anti-Chinese trade ban in Indonesia-preceding the ratification of the Dual Nationality Treaty between Indonesia and the People's Republic of China dramatically altered the context and rationale with which both China and India would interpret and portray the Lhasa Khache.

\section{BANDUNG'S REVENGE}

The Bandung Conference had achieved considerable goodwill across Asia in 1955. All participant countries were deeply committed to a wide range of issues; however, only China and Indonesia had emerged at the end of the meeting with a bilateral 
accord on dual citizenship. The agreement sought to clarify for both nations the citizenship status of Overseas Chinese who had, at the end of Dutch rule in 1946, passively acquired Indonesian citizenship while still being considered ethnically alien. This protocol captured the goal of the Bandung Conference to resolve the undesirable and lingering vestiges of colonialism. It also appeared to proclaim a broader resolution of the persisting concerns many Southeast Asian nations held regarding the ambiguous status of Indian and Chinese communities outside of India and China. While both nations agreed on the desired outcomes, they very quickly discovered they did not see eye to eye on the means by which they sought to achieve that goal.

The unbounded hopefulness that characterized Indonesian president Sukarno's welcoming speech in Bandung in 1955 expressed his desire to "demonstrate to the minority of the world which lives on the other continents that we, the majority, are for peace, not for war." Four years later, this optimism appeared naive. ${ }^{11}$ Particularly in the Indonesian context, the lingering anti-Chinese sentiments combined with Sukarno's strong anti-Communist tendencies caused Indonesia to fear that China's actual intention was to spread Communism among Indonesia’s Overseas Chinese population.

In the years following the Bandung Conference, the social priorities and political convictions had undergone substantial evolutions in both China and Indonesia. As a result, the ratification process for the bilateral accord on dual citizenship exposed the difficulty of transforming lofty sentiments into meaningful actions. In the summer of 1959, a complex combination of religious, ethnic, and political tensions culminated in the Indonesian government placing a ban on all alienowned (overwhelmingly Chinese) rural retail stores. ${ }^{72}$ In response, the Chinese government dispatched embassy employees to impede the ban's implementation by seeking to intimidate Indonesia into reversing its decisions. At an impasse, both nations dug in their heels.

Sensing little movement by the Indonesian government and believing they were winning over international public opinion, China dispatched merchant flotillas to repatriate the Overseas Chinese in Indonesia, culminating in more than 100,000 Chinese returning to China by early 1960 . With both sides believing they had won domestically, Chinese and Indonesian officials finally agreed on terms and, in 1960, ratified a mutually amenable treaty. ${ }^{73}$ Yet China's broad and assertive actions on behalf of the Overseas Chinese in Indonesia were now proclaimed in headline news around the world and began to intermingle in perplexing and unexpected ways for the Khache in Lhasa.

India, by late September 1959, realized that China's handling of its overseas population in Indonesia had created an opening for them in the standoff over the Khache in Tibet. ${ }^{74}$ In the preceding decade, China had deftly managed to organize its domestic ethnic diversity into a state-approved set of fifty-six ethnicities (Ch. minzu shibie) that neatly existed under an overarching framework of Chinese 
citizenship..$^{75}$ But even as the classification had resolved the thorny issue of internal ethnic differences, China's traditional definition of "Overseas Chinese" remained unaltered. As so forcefully demonstrated in Indonesia, this rubric applied only to ethnically Han Chinese. As most Chinese understood the term, Overseas Chinese were those Han Chinese who had lived outside their ancestral homeland for generations but remained Chinese. ${ }^{76}$ As China openly and aggressively demonstrated in their standoff with Indonesia, no amount of time, distance, or even intermarriage with non-Chinese diminished China's ability to declare Overseas Chinese citizens of the People's Republic of China.

The stark differences in China's definition of citizenship in Indonesia from that in Tibet demonstrated to Nehru that Mao's strategy, far from following the Bandung Spirit as a way to lead Asia away from the ideological quarrels of the Cold War, remained at its base an ideological cover to be used selectively to serve China's best interests. As the Indian government began to see the inherent contradictions in the PRC's policies, Nehru hastily seized upon the contradiction between China's oncea-Chinese-always-a-Chinese reasoning inherent in their definition of Overseas Chinese and the refusal to allow the Khache to assert themselves as citizens of India. India now confronted the Chinese government with the fact that having already admitted that the Khache were once Indian, China must allow the Khache, as "overseas Indians," an opportunity to declare themselves Indian citizens.

The first appearance of this diplomatic end run was in Nehru's answers to questions in the Indian Parliament's Upper House (Rajya Sabha) about the status of the Barkor Khache in August 1959 when he succinctly explained: "There is an argument going on between the Chinese government and ourselves as to whether they are to be considered Indian nationals or not. I do not want to take up in answer to the question the story of this argument. We think they are Indian nationals; they claim to be Indian Nationals; they want to be Indian Nationals." ${ }^{7}$ A little over a month later, on September 24, 1959, the Indian government delivered a 2,500-word note to the Chinese embassy in New Delhi that fully explicated their position on the matter. Marking a major shift in Indian tactics as well as tone, the Tibetan Muslim issue was presented not as hinging on whether the Khache had been classified as Tibetan subjects but as the need to equally apply a single policy by two liberated Asian partners. More specifically, India began to use China's demands for its Overseas Chinese population in Indonesia as a criterion by which the Khache in Tibet should be evaluated:

As is well known, a large number of persons of Chinese origin have been resident for decades, if not generations in the various countries of South-East Asia without having actually accepted the nationality of the countries in which they reside. In the Agreement which has been concluded by the People's Republic of China with the Republic of Indonesia, to take only one example, persons of Chinese origin have been given the option to choose between Chinese nationality or the nationality of Indonesia. The Government of India seeks no greater concession in respect of persons 
of Indian origin in the Tibet region of China than the application to them of a principle which the People's Republic of China have accepted in respect of persons of Chinese origin resident outside China. ${ }^{78}$

Realizing that China's primary justification for not recognizing the Khache as Indian had been their historical claim of Chinese control over Tibet, the Indian government's note neatly exposed the intellectual lacuna between China's territorial-based definition of being Tibetan and thus Chinese and the extraterritorial logic deployed to assert Chinese citizenship in Indonesia. The note also explicitly pointed out that the Chinese government's earlier claim that "the Kashmiri Muslims were subject to the jurisdiction of the Tibetan courts, that the selection of their leader was confirmed by the Dalai Lama, that they recognized the Fifth Dalai Lama, and further, that they sometimes fought alongside Tibetan forces" was not in itself enough to "constitute conclusive evidence regarding their Chinese/Tibetan nationality." ${ }^{79}$ In this elegant maneuver, India forced China to acknowledge in the Khache case that ethnic heritage trumped sovereignty. With this tactic, India had limited China's options to two basic choices: (1) either reverse themselves and surrender the ideological high ground to India but relinquish the rights of Chinese in Indonesia or (2) to insist that national boundaries alone defined Chinese citizenship and concede that the Overseas Chinese in Indonesia could not be considered Chinese.

China initially refused to concede either point. Instead, it adopted a twopronged response to stymie India's change of tactics. Internationally, China denied that any double standard existed, insisting that "the Chinese Government cannot agree to the fact that the Government of India should lodge a so-called strong protest against this matter which is purely within the scope of China's internal affairs." ${ }^{\circ}$ Feigning complete innocence, the Chinese maintained that "it is a fact known to all, that foreign nationals in the Tibetan region or any other part of China who desire to return to their country are always given permission" when they apply to the relevant departments. ${ }^{81}$ Most telling, though, was China's meticulous avoidance of being drawn into India's comparison between the Khache in Tibet and the Chinese in Indonesia. Treating this statement as their final word, and despite repeated and insistent requests from India for dialogue, the Chinese refused all of India's attempts to draw them into any further discussion of the topic. Nearly seven months passed before China would again deign to respond to India's repeated questions regarding the Khache.

Internally, however, the Chinese adopted a rather more strident tone and course of action. At the same time that formal communications were being exchanged between the two central governments, inside China officials from both countries were taunting each other, using slights, snubs, and only slightly veiled insults. In particular, the Chinese singled out the Indian consul general, Chhibber, for his role in aiding the Khache. Having served nearly four years in Lhasa, his transfer to Sikkim was highly anticipated by the Chinese authorities stationed in Lhasa. 
In early September, as the day of his departure approached, Chinese officials collectively declined to attend a farewell ceremony in his honor. To make their insult explicit and before his actual departure, Chinese officials came out in full force to attend a welcome party for his replacement, P.N. Kaul. ${ }^{82}$ The Chinese government also ramped up its unambiguously explicit internal attacks against India. Both in the media and as topics for study in political meetings, Indians were repeatedly described as "expansionists" and "interventionists," with the Indian consul and his staff in Lhasa labeled "agents of Imperialists." ${ }_{3}$

If the situation became unpleasant for the Barkor Khache in the first months after the 1959 Uprising, by the end of the summer it became even more so. There was a marked increase in the intensity of an all-out campaign begun with renewed vigor by local Chinese officials to convince the Khache to give up their claims to Indian citizenship. This coercion resumed in earnest on October 21, 1959, when all Khaches were summoned by China's local Lhasa authorities and told they should attend the daily meetings required of all Lhasa residents. They were also "warned that failing compliance they would be subjected to punishment." ${ }^{84}$ Over the next four days, Khache men and women were repeatedly held, individually interrogated, and "harassed and pressed" to accept Chinese nationality. When none agreed, one Khache family was placed under house arrest. ${ }^{85}$

As 1959 came to an end, the Barkor Khache adopted far more exacting and precise measures in their efforts to prove their Indian nationality. They cited instances where the Chinese themselves had acknowledged their foreign status, and they noted how they had educated their children in separate schools (madrasa) from those of the Tibetans prior to 1951. Initially such arguments seemed, at least in Lhasa and Tibet, to gain traction. Quickly, though, the Chinese again altered their tactics and attempted to compel the Khache to abandon their claims, regardless of precedent, and to accept Chinese citizenship. ${ }^{86}$ The Chinese insisted on documentation, not only of Indian ancestry, but of Indian residency or citizenship. This was a requirement that just months earlier the Chinese had not enforced for traders crossing the border and had pointedly resisted in the case of the Overseas Chinese in Indonesia.

As a result, the Khache also changed tactics. Instead of working to provide evidence of their Indian origin, they endeavored to avoid taking any steps, administratively, politically, or socially, that the Chinese could construe as accepting their status as Chinese. ${ }^{87}$ The Khache avoided all meetings that were expressly for Chinese citizens (e.g., not work related or required for other foreign citizens such as the Nepalese) and all large events of a political nature. As Indian consul general Kaul noted, the Khache became cautious when filling out forms that required them to include their ethnicity (Ch. minzu) or documents that were "obviously meant for the Tibetan nationals so as to have a census of them and enable them to prove their bona fides as citizens in every-day transactions." ${ }^{8}$ 
A new dynamic emerged that made an already unpleasant state of affairs even worse. Realizing that being considered Tibetan would be tantamount to accepting Chinese citizenship, Barkor Khache could no longer allow themselves to be treated as equals by their Tibetan neighbors, who were often their relatives. To this end, the Khache increasingly looked to how the Chinese government oversaw the Nepalese living in Lhasa. They insisted on being treated as noncitizens and rejected any administrative designation that grouped them with the local population. As the Chinese slowly began to impose more restrictive administrative control in Lhasa, the Khache could only resist passively and accept harsh sacrifices in order to continue their fight to make their claim to be Indian citizens. In 1959 when the government had begun to control foodstuffs in the capital by issuing ration cards, the Barkor Khache as a group refused to accept the cards because theirs were to be issued by the office for local residents, unlike the Nepalese, whose ration cards were issued by the Lhasa Foreigners Administration Department. Initially, the community dipped into its communal funds to supplement their supplies, but by December, goods on the open market gradually became unavailable, which caused the community considerable privation. ${ }^{89}$

The free-flowing Lhasa that had been so prominent in the early 1950 s was now completely absent. In August 1959, Chinese paper currency became the only legal tender. Even though the purchasing value of Tibetan currency was a fraction of its face value, as fixed by the Chinese government, Tibetans continued to circulate it among themselves, and they still calculated prices with it. The Chinese responded by "flooding the market with their paper currency and withdraw[ing] the silver dollars." This action halted one of the last ways in which the Khache could procure goods and food. ${ }^{90}$ The Chinese opened their own stores and prohibited all Chinese officials and soldiers and their families from purchasing foodstuffs from non-state-owned shops and shops selling foreign commodities. Such regulations were strictly enforced. If any Chinese soldier or official made a purchase from a nonapproved source and were "noticed by Chinese watch-dogs [they] were made to return their purchases and asked to buy those things from the Government shop." ${ }^{11}$

Nor were the Khaches alone in feeling the new restrictions. Over 1,500 Nepalese and Khatsaras and their Tibetan spouses remained in central Tibet. ${ }^{22}$ The few dozen Nepalese traders remaining in Lhasa who were able to import luxury goods continued to thrive, and "Chinese soldiers and cadres flock[ed] to a few Nepalese shops for purchase of watches, cameras and similar luxury [goods]."93 However, for the majority of the Nepalese traders who made their living selling essential goods, life was difficult given that the Chinese had banned the public sale of commodities. Even the sale of yak dung cakes and firewood was prohibited. Even those "pavement hawkers" who plied their goods on the streets of Lhasa were forced off those streets by a variety of tactics. As a result, Nepalese traders were increasingly closing their shops and returning to Nepal. 
Returning to Nepal, however, turned out to be more difficult than it had been only a year earlier. The few Nepalese traders who attempted to return to Nepal found their way blocked by the Chinese, who refused to give them exit visas. Worried they were only making a bad situation worse, some Nepalese tried a more positive approach. Instead of filing protests through their government representatives, they sought to work with, instead of against, the Chinese. At the invitation of the local Chinese authorities, a growing number of Nepalese participated in the various cultural events and public rallies. Roundly praised by the Chinese officials at the time, the Nepalese were sorely disappointed when their participation had little or no effect on their status. The discriminatory pro-Chinese exchange rates, the preferential policies for Chinese traders, and the restrictive trade tariffs all remained immutably in place.

Nor were the Chinese authorities more generous in their dealings with Nepalese officials posted to Tibet. When the Nepalese trade agent posted to Gyantse attempted to travel to Shigatse in June 1959, he was denied transport by the Chinese and forced to travel by horse-drawn cart. Also, if Nepalese traders had Tibetan wives, which included about twenty of the one hundred Nepali traders in Lhasa, the Chinese were prepared to allow their spouses to leave the country on an ordinary exit permit, with one condition. The exit permits would be granted only when the Nepalese consul general certified that "in the case of death of either parent the property would devolve [to] their [Khatsara Tibetan] children." 94 At issue was the fact that the traders often had two families, one in Tibet and one in Nepal. The consul general refused to agree to the Chinese terms because Nepali law specified that inheritance "went to the legitimate collateral descendants living in Nepal rather than the direct descendants of the deceased living together in a family in Tibet." 95 Those Khatsaras who declared themselves Nepali and were granted exit permits for their return to Nepal were often shunned by their Newari in-laws and their "stepmother" (the Nepali trader's Newari wife). ${ }^{96}$ Facing such a difficult decision, the Nepali community remained subdued, unsettled, and concerned about their shifting political status in Tibet.

On October 1, 1959, Lhasa, like towns across China, celebrated National Day. If the PRC's tenth anniversary gave Mao confidence in the path he had forged as the nation's primary architect, his meeting with Khrushchev in early October likely left him feeling deflated. The Soviet Union had remained uncharacteristically silent about events in Tibet and had openly sought to disassociate its India policy from that of China's. ${ }^{97}$ When Khrushchev had visited China in early 1958, he responded to Mao's risk-taking brinksmanship with a shared Cold War comradery. When he visited China a year later, in early October 1959, Khrushchev was in a distinctly different mood.

Coming off of two seminal diplomatic triumphs, the visit of British prime minister Harold Macmillan to Moscow and his own visit to the United States the previous month, Khrushchev felt that the Soviet Union understood how to navigate the deep 
waters of the Cold War. Compared to China's more petulant brinksmanship with India and Taiwan (China shelled the Taiwanese islands without notifying the Soviet Union), Khrushchev's diplomatic maneuvers seemed to be paying dividends that irritated the thin-skinned Mao. Deploying his characteristic bluntness in a conversation with Mao, Khrushchev said, "If you let me, I will tell you what a guest should not say-the events in Tibet are your fault." ${ }^{98}$ To which Mao, clearly peeved, replied, "Nehru also says that the events in Tibet that occurred [are] our fault." Khrushchev, not willing to let the issue drop, needled Mao further by asking him, "If you allow [the Dalai Lama] an opportunity to flee to India, then what has Nehru to do with it? We believe that the events in Tibet are the fault of the Communist Party of China, not Nehru's fault."'100

Though both men eventually let the matter drop, Mao's reluctance to let Khrushchev and the Soviets call out his actions in Tibet suggests that Mao himself realized that he was not entirely blameless in his handling of the events in Lhasa.

\section{LAST STANDS / NEW BEGINNINGS}

By the spring of 1960 tensions between the Chinese and the local Lhasa Khaches had reached a fever pitch. At least twenty-two Barkor Khaches were imprisoned, the community was under increasing pressure to relinquish their claims as Indians, and the stress of the past year was beginning to show. ${ }^{101}$ Chinese authorities, offering no explanation, searched eight Khache residences in the middle of the night. In Lhasa, the rationed food publicly for sale without ration cards was of bad quality and in extremely short supply. Staples like mutton and butter formerly available were virtually unobtainable. In spite of these hardships, the Barkor Khache remained steadfast in their refusal of ration cards, even as the last of their stockpiled supplies were depleted. In early April, they again approached Chinese authorities for permission to emigrate to India. The government officials responded that as Chinese nationals they would not be given permission to travel to India "except on regular [Chinese] passports for trade or meeting relations." ${ }_{102}$

On April 13, the Indian Ministry of External Affairs delivered a withering note to the Chinese embassy in India. It dealt exclusively with Chinese intransigence in resolving the issue of "Kashmiri Indians." The Indian note, written in the curt tone of a schoolmaster scolding a recalcitrant student, did not simply refute the past arguments of the Chinese, but demonstrated the inconsistency of China's policy with regard to the Khache. The Indians pointed out that the Chinese definition of nationality appeared to be "based on principles of jus sanguinis; that is, every descendent of Chinese nationals, irrespective of residence, was considered to be of Chinese nationality." ${ }^{103}$ Following this logic, the Indian government found it baffling that "the Chinese Government should endeavor to challenge the right to Indian citizenship of Indian origin" since it is based on a principle to 
which the Chinese "have traditionally and specifically subscribed, and even now continue to subscribe." ${ }^{104}$

Citing that international law and international opinion were on their side, India's note preemptively refuted three common assertions repeatedly employed by the Chinese to stonewall Indian efforts to break the diplomatic deadlock. First, in answer to the Chinese contention that some Khaches held Chinese documents, the Indians observed that even if Indian nationals have "for the sake of convenience and out of ignorance, taken Chinese papers, the Government of India believe that such assertion does not apply to the bulk of Kashmiri Muslims, " and it should not deprive them of their Indian nationality. ${ }^{105}$ Second, the Indians asserted that even if the Khaches had been in Tibet for more than a generation, they have retained a separate identity and there is no evidence that they "expressly renounced their right to Indian citizenship." Thus it is "unfair and illegal" to force such people to renounce their "assumed" Chinese nationality, given that there is no evidence to suggest they had ever "acquired Chinese nationality much less that they had surrendered it." ${ }^{106}$ And third, the Indian government politely but firmly stated that "it may be expedient to recall the Treaty between the People's Republic of China and the Republic of Indonesia on the question of dual nationality." At its core the treaty affirmed the "principle that all persons who simultaneously hold the nationality of two signatory countries have the right to choose according to their own will which nationality they would wish to adopt." ${ }^{107}$ The note concluded by stating simply that a list of "Kashmiri Muslims" had already been furnished and that "in the spirit of friendship" and "in accordance with International law and custom," "the Chinese Government will facilitate the return to India of persons of Indian origin should they so desire and that local authorities in Tibet will be instructed to remove obstruction in the way of their doing so." ${ }^{108}$

Later that same month, Zhou Enlai arrived in New Delhi for his first visit since 1956. In advance of this summit, the Tibetan Muslims living in Kalimpong sent a telegram to Nehru urging that "your excellency will also take the opportunity to talk about those miserable and deprived of human rights 135 families numbering about 600 people ... [w] ho are still detained in Lhasa and Shigatsi [sic] by the Chinese government." ${ }^{109}$ With tensions running high over border disputes between the two countries, neither side appeared to be in a mood to make concessions. Nehru was under extreme domestic pressure not to concede anything to the Chinese. Although Zhou and Nehru's discussions largely focused on finding a way to avoid aggravating the border disputes between the two countries, India took the opportunity to press China on the Khaches' situation, delivering an informal diplomatic note again stating strongly that in accordance with the Bandung Treaty of Dual Nationality (1955), India maintained that "regardless of the period of their residence abroad, these persons of Indian origin are entitled to Indian nationality."110 
In spite of all these overtures and oral assurances given to Prime Minister Nehru by Zhou Enlai during his visit, China's home government remained silent on the matter.

Perhaps more disconcerting than the lack of diplomatic progress at the summit was the fact that the Chinese authorities in Lhasa appeared to redouble their efforts to coerce the Khaches to renounce their claims. On May 2, 1960, a young Barkor Khache, Abdul Ghani Shakuli, was initially charged with failing to have the proper licenses for his shop. It quickly became known, though, that the Chinese were in fact accusing him of being responsible for a series of anti-Chinese posters that had been posted anonymously on walls around central Lhasa. ${ }^{111}$ Later that month, Shigatse leader Muhammad Sayeed was arrested after nine Shigatse Khache families refused to be strong-armed into attending daily political meetings.

It was on May 19 that Haji Habibullah, a wealthy Lhasa trader, was arrested after a search of his house uncovered a considerable sum of Indian currency hidden inside a quilt. That same day a second Khache, Gulam Muhammad Nyangroo, was also arrested. Although the Chinese found no incriminating evidence, they accused him of also concealing caches of illegal currency. The absence of such currency, the authorities decided, was evidence enough to prove that he must have illegally sent his profits to India. ${ }^{112}$

The intimidation and arrests continued into the next month. On the morning of June 20 and with virtually no advance notice, Chinese officials notified all local Lhasa residents, including the Barkor Khache, of a mandatory rally at the newly constructed Athletic Stadium. All Lhasa residents were instructed to gather at the stadium and to split up into their neighborhood units. When the Barkor Khache insisted they were not "local" and wished to remain as a single unit, they were "told they were not wanted at the meeting and should leave forthwith." ${ }^{113}$ Later they learned that after they had left the stadium, seven Chinese and five Barkor Khache prisoners were paraded before the crowd in the manner of a show trial. Sentences for the Chinese were announced first, with six receiving lengthy prison sentences and the seventh receiving a death sentence. The Chinese prisoner was marched away at once and executed.

The Barkor Khache prisoners were then paraded out before the crowd "handcuffed, and with their heads bent, [to] hear the sentences passed on them." Two of the four prisoners were charged with "incitement of the [Khache] to claim a foreign nationality" and received prison sentences of eleven years. The third, Abdul Ghani Shakuli, the young Khache arrested in May, had the additional charge of illegally affixing anonymous posters with pro-India slogans on walls in the city and received a fifteen-year sentence. The fourth prisoner, Muhammad Umar Nyangroo, was acquitted and immediately freed after it was announced his father had publicly accepted Chinese citizenship. The message to the other Khaches was unmistakable, yet no other Khaches succumbed to the temptation of avoiding prison by agreeing to declare themselves Chinese. ${ }^{114}$ 
By early July, the local authorities were again escalating their campaign of terror tactics, as the Chinese broadened their efforts to menace, bully, and harass key members of the community. Already having shut down the Khaches' shops, the government now attempted to extract as much of their wealth, property, and assets as possible. They were "called every day to area offices, subjected to severe abuse and then admonished to line up with other Tibetans and attend indoctrination meetings." ${ }^{115}$ On July 8 and 9, they were summoned by Chinese authorities and told to provide lists of all their property. Then the Barkor Khaches were ordered to pay, retroactively, six months of sales tax set at an inflated rate. This arbitrarily high tax rate was undoubtedly punitive, and the action was especially galling given that the private exchange and sale of goods with India had been at a standstill for almost a year. In most cases, the shops had been closed since May 2.

Although the Khaches agreed to pay the taxes, a day later they were ordered to return to the municipal offices where, according to Indian consul Kaul's sources, they were subjected to aggressive interrogation and beatings. Two of the Barkor Khache leaders, Barkat Ullah Shahkali and Ibrahim Naik, were singled out and charged with spearheading the "movement in the community for claiming Indian nationality." 116 The two then were beaten repeatedly, forced to stand bent forward with their arms behind their backs for hours on end while rifles were aimed at them, and were told that if they did not acquiesce and accept Chinese nationality "they would be shot dead." ${ }^{117}$ Refusing to back down, they were released; however, as they left, officials told them to abandon their claims for Indian nationality and to attend the political meetings. If they did not, they were threatened, the "worst offenders would be shot" and the others imprisoned. Personal accounts describe the Lhasa Muslims as living "in constant terror" and in "constant fear of being deported or even executed." Others describe how "living conditions were very difficult in Lhasa" because rations were "fixed at ten kilos of cereals a month and one or two pounds of meat every two months."118 Kaul informed his home office that the consulate, acknowledging their deprivations, quietly sold them food on the side, but even this only amounted to half rations. ${ }^{119}$

All summer long the Chinese had been mobilizing parades, political meetings, and propaganda sessions in Lhasa to promote the attempt by Chinese climbers to summit the Chinese (North) face of Mount Everest. On May 27, when news of a successful climb reached the city, the People's Daily reported that "over 30,000 people from all walks of life ebulliently poured into Lhasa's stadium." ${ }^{120}$ Banners declared, “The summiting of Everest is a victory of Mao Zedong Thought!" Over ten thousand of Lhasa's residents lined the streets to welcome the climbers to Lhasa with a banner reading, "The conquest of Everest is the victory of the [Chinese Communist] Party's general line." ${ }^{121}$

At the same time, a new media campaign emerged spotlighting Tibetans who returned to Tibet from India after discovering that life there was worse than in Tibet. ${ }^{122}$ In addition, local cadres, speaking out in neighborhood meetings, began 
suggesting that leaving for Nepal, Sikkim, and Kalimpong was a short-term solution with long-term consequences, since these areas would "eventually fall into Chinese hands." ${ }_{123}$ In the local schools, anti-Khache instruction was included in the children's daily lessons. ${ }^{124}$ All of this occurred against a backdrop of increasing political radicalization, including the emergence of communal organization, such as the creation of common dining halls and day care centers. ${ }^{125}$ A Radio Tibet broadcast called for all Tibetans residing abroad to return to Tibet, claiming that the situation in Tibet had been normalized and that by returning they could "devote their creative energies for the development of their fatherland."126

The Chinese attacks on the Khache peaked in the second week of July with meetings called ostensibly to deal with the new sales tax on traders. At these meetings a dozen Barkor Khaches were subjected to extreme harassment after being accused of crimes and were assaulted for four to five hours at a stretch. Then, almost as suddenly as it had begun, it stopped. In his monthly report for August, Kaul stated, in some bewilderment, that "after the extreme harassment of Kashmiri Muslims during the second week of July, there has been a complete lull in the Chinese attitude towards [them]."127

\section{THE ROAD BACK TO INDIA}

On September 2, 1960, with no advance notice, the top Chinese leaders from the Foreign Bureau in Lhasa convened a meeting of the Barkor Khache and informed them that although they were still considered Chinese nationals, "they would be allowed to proceed to India provided they put in requests voluntarily stating that they wanted to change their nationality from Chinese to Indian." ${ }_{128}$ Acknowledging that their earlier actions had had a dire effect on the Barkor Khaches' food rations, Chinese officials discreetly issued provisions to tide them over until arrangements could be organized for their departure. The Chinese authorities also quickly facilitated the return to Lhasa of three Khache boys who had been studying at minority institutes in Shayan and Beijing so that they could leave China with their families.

Two weeks later, the Chinese Ministry of Foreign Affairs delivered a succinct four-point diplomatic memo to the Indian ambassador in Beijing. The memo characterized the yearlong deadlock over the Khaches' nationality as a misunderstanding entirely of India's own making. It asserted that "the Indian Government repeatedly ignored and distorted the theses of the Chinese government, flagrantly rejected the proposal for a sensible and rational settlement of the question of the nationality of the [Khache]." ${ }_{129}$ The Ministry then insisted that while the Khache had always been treated as Chinese, the "Chinese Government would naturally respect the wishes of the concerned [Khaches] who do not want to remain Chinese." The note went on to suggest that "should they, out of their own will, apply to the Chinese Government for exit or ask to settle their nationality, the Ministry 
of Foreign Affairs believes that the Chinese Government, in view of the friendship between the Chinese and Indian people, will as before effect a sensible and rational settlement of their questions, and will be prepared to give whatever possible consideration to those who apply for exit." ${ }_{130}$ The only caveat to this concession was that the Chinese would not release the five Khache leaders who had "committed offenses against the law." ${ }^{131}$ In essence and in the face of mounting international pressure, the Chinese government conceded every point of the Barkor Khaches' claim of Indian nationality. Within several days' time, Indian consul general P. N. Kaul quickly drew up a list of the Barkor Khaches and issued identification cards with his seal and signature.

The Chinese, perhaps in an attempt to put a good face on what was capitulation on their part or as a final gesture of goodwill prior to the departure of the Barkor Khache community, compensated them almost 40,000 yuan for their destroyed mosque, for the other buildings they owned in central Lhasa, and for any immovable property they left behind. It should be noted, however, that the government drew the line at offering them any payment for the other Lhasa mosques and the thirty acres of property that constituted the Khache Lingka (Ch. kaqi yuan). Perhaps peeved by this treatment, when government officials attempted to present the few destitute families with rations for the journey to India, the Khache council intervened, rejected the government's offer, and instead paid for their food out of council funds.

The Chinese process of arbitrating who was a "Kashmiri Indian," however, immediately became more fraught than originally anticipated. Although the Barkor Khache community initially provided lists of individuals to Kaul, all these individuals had first to receive approval from the Chinese authorities. All three entities - the Khache, the Chinese, and the Indian consulate-initially appeared relatively lenient, allowing most Khaches who identified themselves as Barkor Khache to be issued documentation. This approval included those Khaches who had declared themselves Chinese. Several individuals who had actively and openly advocated for the Chinese against the Barkor Khache also managed to be included. As did two Khaches with Tibetan parents who supported the March Uprising. In the end, the Chinese authorities permitted each of these cases to be allowed to leave for India. ${ }^{132}$ Perhaps the biggest act of leniency was made for a Barkor Khache woman whose husband had worked at the Tibetan Daily and was arrested and imprisoned under "suspicion of their proKMT [Guomindang Nationalist] tendencies." ${ }^{133}$ While he was not released and despite the politically charged circumstances, she and her children were allowed to register as "Kashmiri" and depart to India. ${ }^{134}$

In the early phase of implementing the departures, it appears that several Wapaling Khaches received Chinese approval to leave by asserting some distant relationship to the Barkor Khache. In one case, a Muslim from Xinjiang attempted to claim to be of Khache descent. ${ }^{135}$ But as the Chinese leniency became known, 
the Foreign Bureau soon began to be increasingly vigilant and to demand explicit and demonstrable proof of a relationship to the Barkor Khache. ${ }^{136}$ To be fair, the selection process was complicated. Chinese officials complained that "many people claiming they are of Kaji [Khache] descent are fake. But we have no way of checking." ${ }^{137}$

Given that Khaches lived in most of the cities in central Tibet, living in Lhasa was not a prerequisite for being allowed to leave. Five Khache families in Tsetang and nine families from Shigatse also came to Lhasa to be processed and were adjudged to be of Barkor Khache ancestry and allowed to leave. ${ }^{138}$ Conversely, some Barkor Khaches adamantly refused to leave. In one case, the daughter of one of the Tsetang Khache families who had been working in Lhasa for two years, "point blank refused [to leave Tibet] saying she was happier here." ${ }^{139}$

\section{LEAVING TIBET AND RETURNING “HOME”}

In the third week of September, the first group of Barkor Khaches and their families departed from Lhasa. By early October, nearly five hundred Barkor Khache were transported by Chinese military trucks to Nathula Pass and the border of still-independent Sikkim, where they were met by Indian transport and eventually relocated to the Himalayan hill town of Kalimpong. Over the course of the next six months, nearly a thousand men, women, and children left Tibet, virtually emptying the Barkor Tibetan Muslim communities in Lhasa, Shigatse, and all central Tibetan urban centers. ${ }^{140}$

For those unable to depart with the Barkor Khache, the situation was often bitter. There were others, though, who chose to believe the Chinese press and the rhetoric of the near-constant political meetings that told of India's poor economic conditions. They mocked the departing Khaches, telling them that they were making a horrible mistake and that they were better off in Tibet. Kaul heard that one Chinese official told a teacher applying to leave that "it was no use proceeding to India now as eventually the Chinese would be there in a decade's time." ${ }^{141}$ Inevitably, as each group of Khaches departed from Lhasa, some of those left behind grew envious and despondent. Others, primarily the younger children who had received the greatest degree of Chinese political education, displayed a more "defiant demeanor." ${ }^{142}$

Having altered their stance toward the Khache, the Chinese government then attempted to deal with the even more complicated issue of Nepalese and Khatsara residents. Despite relatively clear terms in the Sino-Nepalese Treaty of 1956, the Chinese had initially refused to issue exit visas to Tibetan wives of Nepalis and Khatsaras. In May, the Chinese authorities finally agreed to issue passports and Nepalese visas to Tibetan spouses of Nepalese men. In August, the Chinese consented to provide passports for the Tibetan wives of Khatsaras even taking the extra effort to issue them transit visas which allowed them to proceed to Nepal 
via India. ${ }^{143}$ On September 20, 1960, about 250 Nepalese and Khatsaras and their Tibetan families left for Nepal via India. ${ }^{144}$ All told, under the terms of the SinoNepalese Treaty of 1956, roughly a thousand Khatsara opted for Nepalese nationality. ${ }^{145}$ A decade and a half later, Dor Bohador Bista, serving as Nepal's consul general, estimated that the "Nepali population of Lhasa proper is about 350 " and the total in central Tibet close to 500 individuals, with only roughly 40 having been born in Nepal. ${ }^{146}$

However, despite the fact that intermarriage with Tibetans was well documented among both the Nepalese Khatsara and the Khache communities, the Chinese refused to grant Indian citizenship to the few cases of half-Indians whose Indian parent was no longer resident in Tibet. The explanation given to the Indian officials was that "a child born of either father or mother who is a Chinese (now Tibetans are called Chinese) will acquire Chinese nationality." ${ }^{147}$ If the manner in which the Chinese handled the Nepalese was protracted and resistant, it still appeared far more cordial than the manner in which they dealt with the Indian officials. ${ }^{148}$

By the end of the year, most of the Lhasa, Shigatse, and Tsetang Khaches who were declared eligible had departed for India. ${ }^{149}$ All that remained in the Barkor Khache neighborhoods were those who had decided to stay behind in Tibet, those Khaches who were imprisoned by the Chinese, and perhaps a dozen Khache families whom the Chinese had rejected as not adequately demonstrating their case for Indian nationality. ${ }^{150}$ The dozen families who remained were often cases of mixed marriages with Tibetans or whose relationship the Chinese authorities adjudged to be too distant from the Barkor Khache. Most continued to receive the support of the Indian consulate to press their case with the Chinese authorities but with little success. ${ }^{151}$

The case of the Khaches who had been arrested was far less clear. The Chinese had asserted in their September note, "As to the few [Khaches] who committed offenses against the law, it is entirely correct for the Government to deal with them in accordance with the law." ${ }^{152}$ Initially, the Chinese resolutely refused to release any Tibetan Muslims who had been arrested even if their only "crime" was to have asserted their Indian citizenship, a status the Chinese government now agreed was correct. It was a decision made purely out of spite. Nor was there consistency even in this decision. Perhaps seeing the incongruity of their stance, a slow trickle of Khaches who had not been formally tried were released between October and December. ${ }^{153}$

On March 30, 1961, the last group of Barkor Khache, composed primarily of the families of prisoners, left Lhasa. Just moments before the group left Yatung for the Nathula Pass, Habibullah Naik was released from prison and allowed to join them. ${ }^{154}$ On the same day, forty Nepalese and twenty Khatsaras also left. ${ }^{155}$ The border crossing of these two large groups marked the end of the two-year ordeal for over a thousand Khaches and some two thousand Nepalese. Left behind 
were five prisoners: Hamibullah Shamo, Abdul Gani Shahkali, Hamidullah Maslie, Haji Abdul Kadir Malik, and Abdul Gani Naik. None would ever see their families again, and all but one, Abdul Gani Naik, would die in prison. ${ }^{156}$

\section{KHACHE BUT NOT "KASHMIRI”}

In a sad coda, just as the last Khaches were making their way over the Nathula Pass and into India, the Wapaling Khaches also began demanding to be allowed to emigrate to India. Witnessing the success of the Barkor Khache departures, many Wapaling Khaches immediately petitioned to be allowed to leave as welland some had succeeded, which only increased their aspirations. Given the large number of intermarriages and the complex family trees among the various Khache and Buddhist Tibetan communities, the maneuver is not as devious as might have appeared. However, Chinese officials quickly limited the criteria by which one could claim to be "Kashmiri Indian." 157

As 1960 came to an end, increasing numbers of Wapaling Khaches came to the Indian consulate to consult with Kaul, even though there was the risk of having one's name (and number of visits) noted by the ever-present Chinese guard. The Wapaling continued to press, using the legal channels that had succeeded for the Barkor Khache. From the outset, Kaul declared quite openly that "there is no question of their being Indian citizens."161

Throughout the spring, the Wapaling Khache slowly escalated their demands. They boycotted praying at the Grand Mosque (only just reconstructed after its destruction in the 1959 Uprising), with a majority of them beginning to carry out their prayers and activities in the Small Mosque in the Barkor neighborhood. ${ }^{162}$ By May they realized that the Chinese government had more or less finished processing all the individuals they intended to allow to leave for India. It was then that aroup of ninety Wapaling Khache families, roughly two-thirds of the thousand-strong community, began adopting the same tactics as their now-departed neighbors. The remaining families resigned themselves to their circumstances and refused to join the increasingly belligerent actions of their neighbors. ${ }^{163}$

The Chinese government, realizing perhaps that they had the upper hand now that the worst of the crisis had passed, consistently told them that there was absolutely no chance they would be allowed to leave. However, the government officials never reverted to the pattern of harassment and intimidation that had typified their actions in the past year, even opening a Muslim halal (Ch. qingzhen) bakery in the Wapaling neighborhood in an attempt to ingratiate themselves with the Wapaling Khaches. ${ }^{164}$

Such efforts by the Chinese did little to alter their stance. Desperate to obtain a positive response to their request, nearly fifty Wapaling Khaches resigned their government positions in August 1961, refused their ration cards, rejected the Chinese household registration (Ch. hukou), and moved north of Lhasa to the 
Muslim cemetery and small mosque in Dokdé (Tib. dog sde; Ch. Duodi). ${ }^{165}$ There they pitched their tents and began a campaign of passive resistance. Other accounts describe protests in front of government offices, some Wapaling children being removed from the schools, and several older students, at university elsewhere in China, returning to join in their family's protest efforts. Kaul stated that "local authorities have recently been warning Tibetan hawkers and others not to help the [Wapaling] with the sale of food and loan of tents as long as they continued to live in the said garden." ${ }^{166}$ Local Chinese officials, showing continued restraint, labeled their actions simply as a "contradiction amongst the masses" rather than the much more severe designation "enemies of the state."

As political tensions rose the sudden shift in the Chinese government's position led to accusations of Chinese infiltrators among those early Wabaling Khaches allowed to leave for India. In India, concern centered on several pro-Chinese Wapaling Khaches who were suspiciously, some felt, included among the Barkor Khaches approved by the Chinese government's Foreign Bureau in Lhasa to be allowed to emigrate to India. This struck many Khaches as particularly odd because other individuals with much stronger cases for Barkor Khache identity had been denied permission to leave Tibet. Attention quickly focused on the Wapaling Khache Habibullah Batt and his Nepalese Khatsara wife. ${ }^{1{ }^{8}}$ With no close ties in the Barkor Khache community, distrust of his actual motives was accentuated by the fact that the Chinese government had granted him an exit permit with other Tibetan Muslims instead of assigning him the seemingly more appropriate designation of Nepalese and returned to Nepal. The questionable circumstances surrounding his status, along with the highly charged political atmosphere, caused Batt and his family to be cast out of the Tibetan Muslim community and forced to leave Kalimpong only weeks after their arrival.

Batt's swift return to Lhasa after leaving Kalimpong suggests that such suspicions were not misplaced. In late 1961, Batt immediately came to the attention of Arvind Deo, who had just arrived in Lhasa to replace P. N. Kaul as consul general for India. In his monthly report Deo identified Batt as a Wapaling Khache who repeatedly met with the disgruntled Wapaling Khaches attempting to leave India. In these meetings, Batt painted "a grim picture of life in India" and spoke of "grave reprisals" by the Chinese authorities if they continued to claim Indian nationality. ${ }^{159}$ Batt's special status seems to be confirmed by the fact that he received "special permission" to hold on to his Nepalese passport and "carried on his [religious] work even when the Grand Mosque was closed from 1966 to $1981 . " 160$

In November, Habibullah Batt led a group of thirty Wapalings out to the Dokdé group in an attempt to convince those Wapaling holdouts to cease any further resistance and return to their homes. Habibullah Batt's leadership role is significant, given that as a Wapaling Khache (married to a Khatsara) he had managed to be among those allowed to join the Barkor Khaches in emigrating to India the 
year before, and, it was believed among Chinese officials, his voice might help convince the demonstrating Khache that they would be better off remaining in China. ${ }^{167}$ When his efforts to convince the renegade Wapalings failed, he and his allies issued thinly veiled warnings of Chinese retaliation if they persisted in their claims of Indian nationality. As the Wapaling protests continued, the Chinese officials began to grow weary of the movement and to fear political reprisals from their superiors if the protests were discovered. The authorities began to bring the Wapaling leaders to Lhasa in order to interrogate them, and Habibullah Batt continued to be dispatched by Chinese officials in increasingly futile efforts to persuade the Wapalings to return to their homes in Lhasa. ${ }^{168}$

It was at this point, in mid-December 1961, that the State Council (Ch.guowuyuan) became involved. According to Chinese Foreign Ministry Archive documents, the Wapaling Khaches had become increasingly disruptive, embarrassing Chinese officials by interrupting a banquet hosted for them at the Nepali consulate. ${ }^{169}$ The Lhasa municipal government and the Party committee met to discuss how to proceed. They agreed that the Khaches should be fully investigated and arrested if found guilty of resisting the government's call for them to cease their demonstrations. ${ }^{10}$ In what became known as the Lhasa Muslim Incident of 1961 (Tib. hu'i rigs kyi rnyog gra), the government's patience came to an end.

More than a dozen individuals were arrested and threatened with the use of military force to compel the remaining families to return to the city. In the end, without food, deprived of income, and forced to beg to stave off starvation, they slowly returned to their homes, destitute and defeated. ${ }^{171}$ In his account of the period, Tubten Khétsun suggested that some Wapalings persisted in their resistance into 1963: "a few families were still stubbornly refusing ration cards, and their children were among the beggars along the Lingkor path during the fourth month Saga Dawa (Buddha's Birthday) holiday (Tib. sa ga zla ba dus chen) that year."172

The Wapaling Khaches' lingering reputation as collaborators and pro-Chinese diminished over the years, partly as a result of the manner in which the larger Khache community was split but also because of the hardships they had faced in 1961-62. But even two decades later when Catriona Bass arrived in Lhasa as an English teacher and the topic came up among her Tibetan friends, they expressed sympathy and even pity, noting, "Life has been difficult for them.... In the beginning of the Sixties, their situation was almost worse than ours." ${ }^{173}$ Perhaps like many lingering prejudices, those past disputes, rifts, and altercations were forgotten when the violent political campaigns of the Cultural Revolution reached Tibet and in their brutality erased many of the earlier, now seemingly less important disagreements. 